\title{
Phycoremediation of wastewater: heavy metal and nutrient removal processes ${ }^{1}$
}

\author{
Phykoremediacja ścieków: \\ usuwanie metali ciężkich i biogenów (N, P)
}

\footnotetext{
* Dr inż. Anna Kwarciak-Kozłowska, mgr Lucyna Sławik-Dembiczak, mgr inż. Bartłomiej Bańka, Department of Environmental Engineering and Biotechnology, Institute of Environmental Protection, Czestochowa University of Technology, Brzeźnicka 60A St., 42-200 Czestochowa, e-mail: akwarciak@is.pcz.czest.pl, Islawik@is.pcz.czest.pl, iranek@wp.pl
}

Keywords: phycoremediation, Chlorella vulgaris, Scenedesmus armatus, bioaccumulation, nutrient removal Słowa kluczowe: phykoremediacja, Chlorella vulgaris, Scenedesmus armatus, bioakumulacja, usuwanie składników odżywczych

\section{Abstract}

Phycoremediation is the use of algae for the removal or biotransformation of pollutants from wastewater. The study is a novel attempt to integrate nutrient ( $\mathrm{N}$ and $\mathrm{P}$ ) removal and some heavy metals (iron, manganese and zinc) bioaccumulation from municipal wastewater using two microalgae species: Chlorella vulgaris and Scenedesmus armatus. The Chlorella vulgaris showed higher removal of total nitrogen (TN) both in influent and effluent wastewater than Scenedesmus armatus. Nevertheless, more than $51 \%$ of total phosphorus (TP) in effluent and 36\% in influent wastewaters were removed by Scenedesmus armatus. More efficient microalga in heavy metal removal in influent wastewater was Scenedesmus armatus. The results showed that Chlorella vulgaris was appropriate for TN removal and bioaccumulation of heavy metals from effluent wastewater. Nevertheless, Scenedesmus armatus was highly preferable for heavy metals removal from influent wastewater.

(c) IOŚ-PIB

\section{INTRODUCTION}

The term phycoremediation was introduced by John [John 2000] to refer to the remediation carried out by algae. It comprises several applications: nutrient removal (i.e. nitrogen and phosphorus) from municipal wastewater and effluents rich in organic matter, nutrient and xenobiotic removal with the aid of algae-based biosorbents, treatment of acidic and metal wastewater, carbon dioxide sequestration, transformation and degradation of xenobiotics and detection of toxic compounds with the aid of algae-based biosensors [John 2000, Olguin 2003].

The use of microalgae for the municipal wastewater treatment has been a subject of research for several years. Actually, extensive work has been conducted to explore the feasibility of using microalgae for wastewater treatment, especially for the nutrients (nitrogen and phosphorus) removal [Wang et al. 2013, Wang et al. 2010], which is very favourable to other conventional technologies [de la Noie et al. 1992]. Concentrations of several heavy metals have also been shown to be reduced by the cultivation of microalgae [Arunakumara, Xuecheng 2008]

\section{Streszczenie}

Phykoremediacja to proces usuwania lub biotransformacji zanieczyszczeń ze ścieków przy pomocy glonów. Celem pracy badawczej było zintegrowanie procesu usuwania biogenów $(N, P)$ i bioakumulacji niektórych metali ciężkich (żelazo, magnez, cynk) z ścieków komunalnych przy pomocy dwóch gatunków mikroglonów: Chlorella vulgaris i Scenedesmus armatus. Wyższy stopień usunięcia azotu ogólnego zarówno w ściekach surowych, jak i oczyszczonych wykazał gatunek Chlorella vulgaris. Z kolei Scenedesmus armatus spowodowało usunięcie fosforu ogólnego w 51\% ze ścieków oczyszczonych i 36\% z ścieków surowych. Większy stopień usunięcia metali ciężkich uzyskano przy pomocy Scenedesmus armatus. Wykazano, że do usuwania azotu ogólnego i bioakumulacji metali ciężkich ze ścieków oczyszczonych odpowiedniejsze są glony Chlorella vulgaris. Z kolei w celu usuwania metali ciężkich z ścieków surowych preferowane są glony Scenedesmus armatus.
One of the most extensively used microalgae for nutrient removal was Chlorella sp. However, there is a necessity to find another high-efficient microalga useful for nutrient and heavy metal removal [Rezaei et al. 2012].

Microalgae play an important role in biological degradation of heavy metals [Arunakumara, Xuecheng 2008]. In particular, the bioaccumulation of heavy metals is dangerous [StańczykMazanek et al. 2007]. The toxicity of heavy metals may result in diverse effects, which depend on types of algae, features and concentrations of the metal and environmental conditions. Therefore, the bioaccumulation could be at different levels and the uptake of heavy metal can be various [Doshi et al. 2008, Kacprzak et al., 2014].

The aim of this study was to assess the removal efficiencies of nitrogen and phosphorus from influent and effluent municipal wastewater using Chlorella vulgaris and Scenedesmus armatus. Further, the concentration of heavy metals ( $\mathrm{Fe}, \mathrm{Mn}$ and $\mathrm{Zn}$ ) in wastewaters and their removal efficiency were determined. 


\section{MATERIALS AND METHODS}

\subsection{Materials}

The microalgae strains: Chlorella vulgaris BA0002 and Scenedesmus armatus were obtained from the Culture Collection of Baltic Algae. Pre-cultures were carried out in 300-ml Erlenmeyer flask with light flux density $60 \mu \mathrm{mol}$ photon $\mathrm{m}^{-2} \cdot \mathrm{S}^{-1}$, light-dark cycle $16 \mathrm{~h} / 8 \mathrm{~h}$, temperature $30^{\circ} \mathrm{C}$. Chlorella strain was cultured in BG11 medium. Municipal wastewater including influent and effluent was taken from wastewater treatment plant in Poland. This plant treated both domestic and industrial wastewaters by the traditional activated sludge method. The influent and effluent wastewaters were filtered through a $0.22-\mu \mathrm{m}$ pore size membrane. Then, the wastewaters were moved to 300-ml Erlenmeyer flasks for microalgae cultivation. The characteristics of influent and effluent wastewaters are listed in Table 1

Table 1. Physico-chemical parameters of wastewater

\begin{tabular}{|c|c|c|}
\hline \multirow{2}{*}{} & \multicolumn{2}{|c|}{ Wastewaters } \\
\hline $\mathrm{pH}(-)$ & Influent & Effluent \\
\hline $\mathrm{COD}\left(\mathrm{mg} \cdot \mathrm{L}^{-1}\right)$ & 7.65 & 7.12 \\
\hline $\mathrm{NH} 4-\mathrm{N}\left(\mathrm{mg} \cdot \mathrm{L}^{-1}\right)$ & $30.8 \pm 0.12$ & $3.92 \pm 0.22$ \\
\hline $\mathrm{TN}\left(\mathrm{mg} \cdot \mathrm{L}^{-1}\right)$ & $202.6 \pm 2.33$ & $8.2 \pm 0.227$ \\
\hline $\mathrm{TP}\left(\mathrm{mg} \cdot \mathrm{L}^{-1}\right)$ & $3.2 \pm 0.02$ & $1.6 \pm 0.02$ \\
\hline Zinc $\left(\mu \mathrm{g} \cdot \mathrm{L}^{-1}\right)$ & $119.56 \pm 0.23$ & $323.5 \pm 1.24$ \\
\hline Iron $\left(\mu \mathrm{g} \cdot \mathrm{L}^{-1}\right)$ & $158.27 \pm 1.02$ & $1560.0 \pm 3.41$ \\
\hline Manganese $\left(\mu \mathrm{g} \cdot \mathrm{L}^{-1}\right)$ & $133.08 \pm 0.68$ & $320.3 \pm 0.98$ \\
\hline
\end{tabular}

\subsection{Methods}

The total nitrogen (TN) was determined using a TOC analyser. Determination of ammonia $\left(\mathrm{NH}_{4} \mathrm{~N}\right)$ was conducted by titration with sulphuric acid. The total phosphorus (TP) was determined according to the standard EPA-600/4-79-020. Wastewater samples were analysed for iron (Fe), manganese (Mn) and zinc ( $\mathrm{Zn}$ ) through inductively coupled plasma mass spectrometry (ICPMS) analyser. For analysis of these metals, samples were acidified by the addition of about $1 \mathrm{ml}$ of concentrated suprapur nitric acid. All the analyses were carried out adopting standard methods of analysis. The $\mathrm{pH}$ was measured by potentiometric method according to the standard PN-EN 12176:2004.

\subsubsection{Analysis of wastewater}

The heavy metals concentration in influent and effluent wastewater were determined before the experiment and at specified intervals: 1, 3, 5, 10, 20, 30 and 60 minutes (1 h), 2, 3 and $24 \mathrm{~h}$. The $\mathrm{pH}$ of the wastewater samples was measured at all the intervals. Chemical oxygen demand (COD), TN, TP and ammonia nitrogen $\left(\mathrm{NH}_{4} \mathrm{~N}\right)$ of samples were determined in the laboratory before and after their treatment with the microalgae.

\subsubsection{Batch experiment}

The batch experiments were run in Erlenmayer flask of $300 \mathrm{ml}$ with light flux density $60 \mu \mathrm{mol}$ photon $\mathrm{m}^{-2} \cdot \mathrm{S}^{-1}$, light-dark cycle $16 \mathrm{~h} / 8 \mathrm{~h}$, at temperature $30^{\circ} \mathrm{C}$. Each flask was filled with a known volume of the sample (wastewater) and then using a flask shaker was stirred. The samples were withdrawn from the shaker at predetermined time intervals, filtered and analysed for the heavy metals concentration. At the same time, the $\mathrm{pH}$ was measured. The treatment was varied between 0 and 1440 min for influent and effluent wastewaters and both the microalgae species. Each treatment was conducted with three replicates.

\section{RESULTS AND DISCUSSION}

The Chlorella vulgaris showed higher removal of TN both in influent and effluent wastewater than Scenedesmus armatus ( $\mathrm{Ta}$ ble 2). Interestingly, the higher concentration of nutrients led to the higher removal ratio of $\mathrm{TN}$. Moreover, the removal rate of TN in effluent wastewater using Chlorella vulgaris was approximately $70 \%$, whereas the removal rate of TN for Scenedesmus armatus was lower (approximately 54\%)

The removal of $\mathrm{NH}_{4} \mathrm{~N}$ was higher than $27 \%$ in influent wastewater phycoremediated by Chlorella vulgaris, whereas for Scenedesmus armatus it was approximately $22 \%$. In effluent, the removal effect of $\mathrm{NH}_{4} \mathrm{~N}$ was not as good as in influent wastewater and it was calculated 3\% and 5\% for Scenedesmus armatus and Chlorella vulgaris, respectively. The similar results were reported by Wang et al. [2013] The removal rate of TP is shown in Table 2. More than 51\% TP in effluent and $36 \%$ in influent wastewaters were removed by Scenedesmus armatus, respectively. It means that the microalga could use phosphorus at low concentration. This phenomenon was also found in Chlorella vulgaris. The similar results were reported by Wang et al. [2013].

Therefore, the use of microalgae, such as Chlorella vulgaris and Scenedesmus armatus, in wastewater reducing nutrients is a promising approach for coupled wastewater treatment and biomass production.

The COD reduction was determined (Table 2). However, the COD reduction was insignificant both in effluent and influent wastewater The two algal species used in this study were able to accumulate $\mathrm{Fe}, \mathrm{Mn}$ and $\mathrm{Zn}$ cations with high efficiency. The degree of metal association with the cells was in direct proportion to the external metal concentration. Determination of the $\mathrm{pH}$ values during the metal biding reactions showed that the $\mathrm{pH}$ was maintained within $\mathrm{pH} 7.65$ to $8.24 \pm 0.02$ in influent wastewater and $\mathrm{pH} 7.12-7.51$ in effluent wastewater for both microalgae species.

Metal accumulation increased with metal concentration in wastewaters; thus, the higher removal rate was achieved in influent than in effluent wastewater (Figs. 1 and 2). Bioaccumulation of heavy metals differed in influent and effluent wastewater. In the present study, it was found that all assessed metal cations were accumulated rapidly.

More efficient microalga in heavy metal removal in influent wastewater was Scenedesmus armatus. The zinc $(\mathrm{Zn})$ removal efficiency was highest at $83.64 \%$ and $89.72 \%$ for Chlorella vulgaris (after 1440 min of bioaccumulation) and Scenedesmus armatus (after 30 min of bioaccumulation). The manganese (Mn) removal efficiency was highest at $62.63 \%$ and $15.17 \%$ for Scenedesmus armatus (after first minute of bioaccumulation) and Chlorella vulgaris (after $1440 \mathrm{~min}$ of bioaccumulation). The manganese bioaccumulation by Scenedesmus armatus was very high in the first minute of process $(62.63 \%$ at first minute, $42 \%$ at the third and the fifth minutes). Then, the removal efficiency of the element has decreased. The iron (Fe) removal efficiency was also very high using Scenedesmus armatus. The highest removal efficiency of the element was at $75.35 \%$ (at $180 \mathrm{~min}$ ), $65.33 \%$ (after $60 \mathrm{~min}$ ) and $60.26 \%$ (after $120 \mathrm{~min}$ )

Unlike influent, the zinc $(\mathrm{Zn})$ removal efficiency was highest at 83.64\% after 1440 min of process for Chlorella vulgaris. Nevertheless, the bioaccumulation of zinc by Scenedesmus armatus was at $45 \%$ after 120 min of process. The higher efficiency of manganese was also assessed for Chlorella vulgaris, and the maximum (68.64\%) was achieved after 1440 min. The bioaccumulation of iron (Fe) by Scenedsmus armatus was higher in each of analysed time and the maximum was $56 \%$ at $1440 \mathrm{~min}$. Thus, Scenedesmus armatus is better than Chlorella vulgaris in iron removal from effluent wastewater. 
Table 2. Total nitrogen (TN) content, total phosphorus (TP) content, ammonium ( $\left.\mathrm{NH}_{4} \mathrm{~N}\right)$ content and chemical oxygen demand (COD) of wastewater removed by Chlorella vulgaris and Scenedesmus armatus before and after the process

\begin{tabular}{|c|c|c|c|c|c|c|}
\hline & \multicolumn{6}{|c|}{ Wastewater } \\
\hline & \multicolumn{3}{|c|}{ Influent } & \multicolumn{3}{|c|}{ Effluent } \\
\hline & \multirow[b]{2}{*}{ Initial value } & \multicolumn{2}{|c|}{ Terminal value } & \multirow[b]{2}{*}{ Initial value } & \multicolumn{2}{|c|}{ Terminal value } \\
\hline & & $\begin{array}{l}\text { Chlorella } \\
\text { vulgaris }\end{array}$ & $\begin{array}{l}\text { Scenedesmus } \\
\text { armatus }\end{array}$ & & $\begin{array}{l}\text { Chlorella } \\
\text { vulgaris }\end{array}$ & $\begin{array}{l}\text { Scenedesmus } \\
\text { armatus }\end{array}$ \\
\hline $\mathrm{pH}(-)$ & 7.65 & 8.24 & 8.22 & 7.12 & 7.51 & 7.51 \\
\hline $\mathrm{COD}\left(\mathrm{mg} \cdot \mathrm{L}^{-1}\right)$ & $424.6 \pm 2.67$ & $348.6 \pm 3.22$ & $414.82 \pm 5.58$ & $42.3 \pm 3.24$ & $40.8 \pm 3.58$ & $39.22 \pm 2.80$ \\
\hline $\mathrm{NH} 4-\mathrm{N}\left(\mathrm{mg} \cdot \mathrm{L}^{-1}\right)$ & $30.8 \pm 0.12$ & $22.26 \pm 0.12$ & $23.94 \pm 0.22$ & $3.92 \pm 0.22$ & $1.12 \pm 0.02$ & $3.08 \pm 0,15$ \\
\hline TN $\left(m g \cdot L^{-1}\right)$ & $202.6 \pm 2.33$ & $168.3 \pm 2.33$ & $187.6 \pm 2.35$ & $25.56 \pm 0.23$ & $7.8 \pm 0.15$ & $11.92 \pm 0.39$ \\
\hline $\mathrm{TP}\left(\mathrm{mg} \cdot \mathrm{L}^{-1}\right)$ & $5.02 \pm 0.02$ & $4.3 \pm 0.12$ & $3.2 \pm 0.22$ & $1.6 \pm 0.02$ & $0.85 \pm 0.36$ & $0.78 \pm 0.05$ \\
\hline
\end{tabular}

\section{CONCLUSIONS}

The results from this study demonstrate the feasibility of nutrient removal (nitrogen and phosphorus) of two microalgae, Chlorella vulgaris and Scenedesmus armatus, in influent and effluent wastewaters. Moreover, the capability of heavy metal bioaccumulation was assessed. Conducted experimental studies led to the following conclusions:

- Chlorella vulgaris is more appropriate than Scenedesmus armatus for TN removal.

- In both microalgae, the removal efficiency of $\mathrm{NH}_{4} \cdot \mathrm{N}$ was rather low and estimated 22\% and 27\% for Scenedesmus armatus and Chlorella vulgaris, respectively.

- The COD reduction was insignificant for Scenedesmus armatus (2.3\% in influent and $7.2 \%$ in effluent wastewater). Similar results were obtained by Chlorella vulgaris in effluent wastewater. Higher reduction of COD was obtained by Chlorella vulgaris in influent wastewater.

- In both microalgae, the removal efficiency of TP was similar and estimated approximately $50 \%$ in effluent and approximately $35 \%$ in influent wastewater.

- The highest efficiency in heavy metal removal in influent wastewater was achieved according to zinc and assessed 83.64\% and $89.72 \%$ for Chlorella vulgaris and Scenedesmus armatus, respectively.
- The manganese bioaccumulation by Scenedesmus armatus from influent wastewater was very high in the first minutes of process (approximately 60\%).

- The iron (Fe) removal efficiency from effluent wastewater was also very high using Scenedesmus armatus.

- Chlorella vulgaris is better than Scenedesmus armatus in heavy metals removal (i.e. zinc and manganese) from effluent wastewater.

- The $\mathrm{pH}$ increase, which is mediated by the growing algae, also induces phosphorus precipitation and ammonia stripping to the air.

The results obtained showed that Chlorella vulgaris was appropriate for TN removal and bioaccumulation of heavy metals from effluent wastewater. Nevertheless, Scenedesmus armatus was highly preferable for heavy metals removal from influent wastewater. Nowadays, the research is concern on the phycoremediation using mixed population of microalgae.

\section{ACKNOWLEDGEMENTS}

The financial support from the Ministry of Science and Higher Education in Poland is greatly acknowledged. The study has been funded by BS/MN-401-301/14.

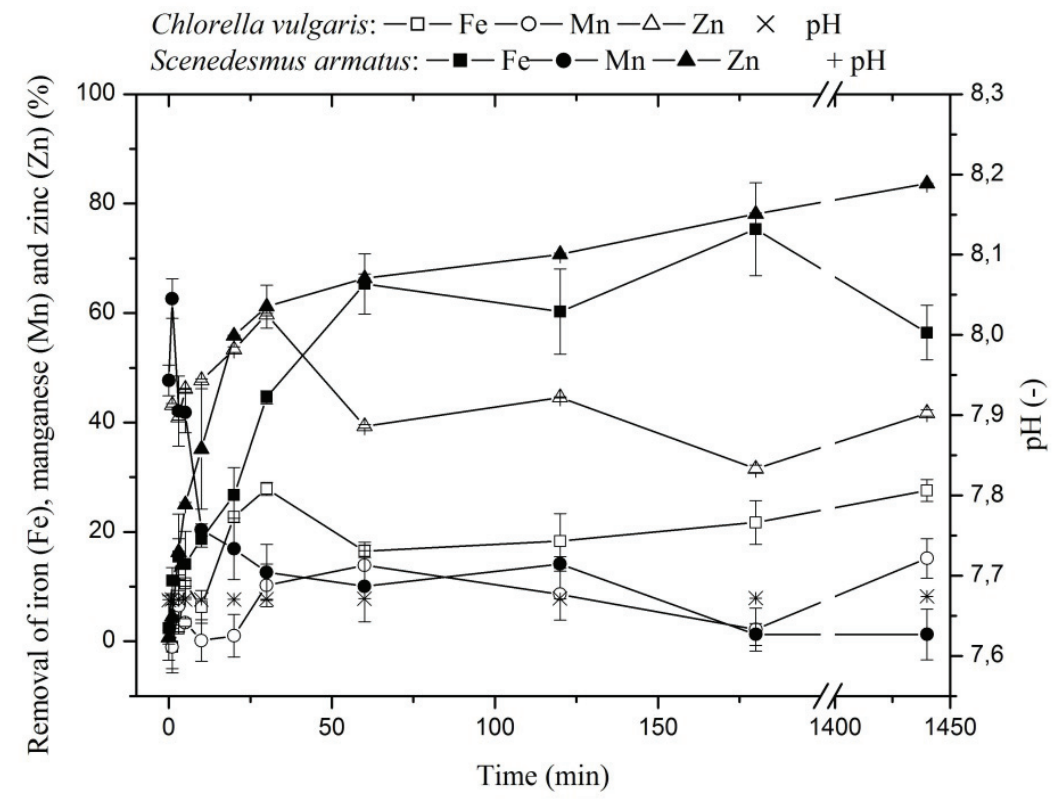

Fig. 1. Correlation between removal of iron, manganese and zinc cations from wastewater influent using Chlorella vulgaris and Scenedesmus armatus and $\mathrm{pH}$ value (mean $\pm \mathrm{SD})$ 


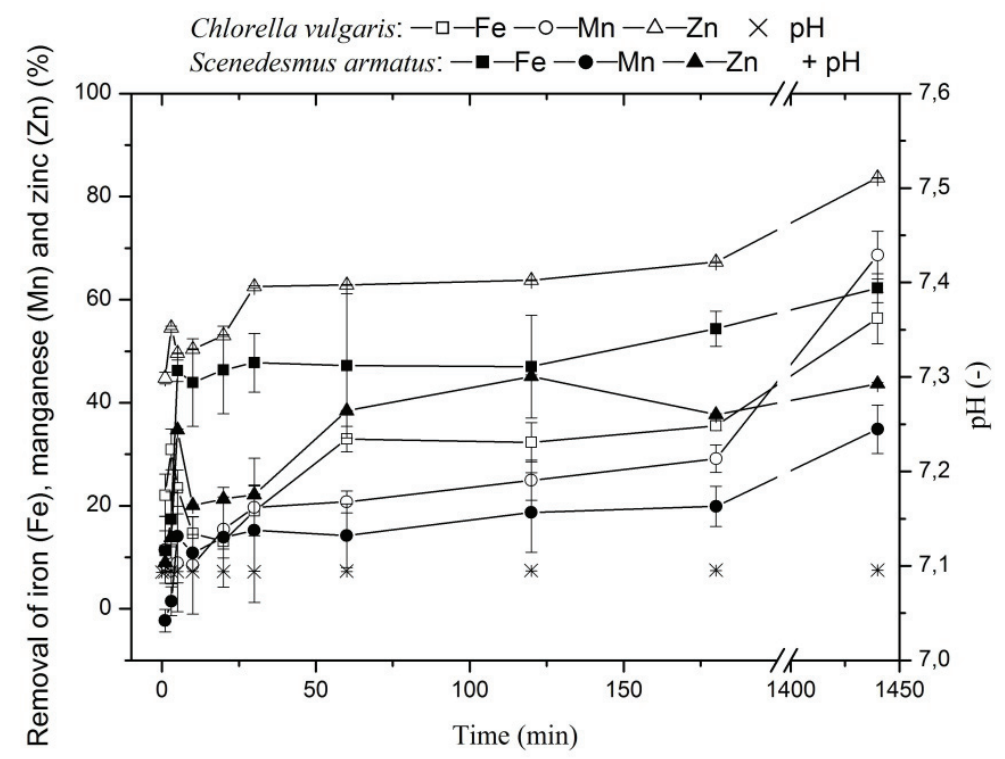

Fig. 2. Correlation between removal of iron, manganese and zinc cations from wastewater effluent using Chlorella vulgaris and Scenedesmus armatus and $\mathrm{pH}$ value (mean $\pm \mathrm{SD})$

\section{REFERENCES}

ARUNAKUMARA K.K.I.U, XUECHENG Z. 2008. Heavy metal Bioaccumulation and Toxicity with special Reference to Microalgae. J. Ocean Univ. Chin. 7: 25-30.

DE LA NOIE J., LALIBERT G., PROULX D. 1992. Algae and wastewater. Journal of Applied Phycology 4: 247-254.

JOHN J. 2000. A self-sustainable remediation system for acidic mine voids. In: Proceedings of the $4^{\text {th }}$ International Conference of diffuse pollution: 506-511, Bangkok.

OLGUIN E.J. 2003. Phycoremediation: key issues for cost-effective nutrient removal processes. Biotechnology Advances 22: 81-91.

REZAEI H., KULKARNI S.D., SAPTARSHI P.G. 2012. Study of Physical Chemistry on Biosorption of Zinc by Using Chlorella pyrenoidosa. Russian Journal of Physical Chemistry 86: 1332-1339.
STAŃCZYK-MAZANEK E., KĘPA U., STĘPNIAK L. 2007. Bioaccumulation of Heavy Metals in Plants from Sewage Sludge Substrates. Polish Journal of Environmental Studies 16: 465-469.

WANG CH., YU X., LV H., YANG J. 2013. Nitrogen and phosphorus removal from municipal wastewater by the green alga Chlorella sp. Journal of Environmental Biology 34: 421-425.

WANG L., MIN M., LI Y., CHEN P., CHEN Y., LIU Y., WANG Y., RUAN R. 2010. Cultivation of Green Algae Chlorella sp. in Different Wastewater from Municipal Wastewater. Appl Biochem Biotechnol 162: 1174-1186.

ZABOCHNICKA-ŚWIAৃTEK M. 2010. Algae - Feedstock of the Future. Archivum Combustionis 30: 225-236.

ZIELIŃSKA A., MICHALAK I., CHOJNACKA K. 2007. Zastosowanie alg w oczyszczaniu ścieków I żywieniu zwierząt. Chemik 60, 11: 534-543. 